\title{
TRADE SUSTAINABILITY IMPACT ASSESSMENT - TRANSFORMATION AND MODELLING: ROLES OF THE EUROPEAN UNION AND SWITZERLAND
}

\author{
LEILA NEIMANE \\ University of Latvia, Faculty of Law, 19 Raina Blvd., Riga, LV-1586, \\ Latvia - Erasmus Mundus fellow, \\ University of Pretoria, Faculty of Law, cnr Lynnwood Road and Roper Street, \\ Hatfield, Pretoria, 0028, South Africa \\ E-mail address: leila.neimane@eia.lv \\ ILVA RUDUSA \\ Latvia University of Agriculture, Faculty of Information Technologies, \\ Liela street 2, Jelgava, LV-3001, Latvia \\ E-mail address: ilva.rudusa@1lu.lv
}

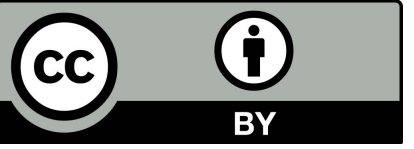

\begin{abstract}
This paper as a theoretical perspective based on a literature study addresses trade sustainability impact assessments. They are defined and designed to enhance free trade agreements and conducted either by regional organizations or individual states.

The paper includes sections on the historical background of the different generations of the impact assessments (sustainability impact assessment, human rights impact assessment) used in the context of international trade, its impact on human rights and relation to environmental refugees, as well as, the influence of the European Union and Switzerland as the international players in shaping these assessments. The conclusion reached in this paper is that although diverse assessment tools are available, there is a need to encourage their greater adoption and use, based upon a holistic approach. The paper highlights the need for the use of theoretical models of trade sustainability impact assessment.

Key words: sustainability impact assessment, trade sustainability impact assessment, human rights impact assessment, climate change, environmental refugees

\section{INTRODUCTION}

The world has become more complex over time, with various parallel symptomatic processes that challenge the achievability of sustainable development and the eradication of extreme poverty. These issues are multi-scalar, multidimensional, and multi-sectoral at the same time.
\end{abstract}


In recent years, despite the fact that "a great number of legally binding and non-legally binding goals and objectives have been adopted as part of over 500 multilateral environmental agreements" (UNEP, 2012, p. 1), sustainable development, in conjunction with impact assessment, is still "a hot topic" both in international and regional negotiations; however, the world remains far from achieving many of the sustainable development goals. UNEP Executive Director and Under-Secretary-General of the UN Achim Steiner (2012) rightly states that there is a "fundamental question as to why the aims and goals of these (...) instruments have often fallen far short of their original ambition and intentions". He comments that the vast majority of these goals are too aspirational in nature and not specific or measurable enough. In order to ensure that internationally agreed goals do not remain elusive, there is a call for clear ways to measure progress towards sustainable development and to track "sustainability progress, strengthen accountability and facilitate learning" (United Nations Environment Programme, 2012).

In light of the above-mentioned issues, the main aim of this paper is to assess the trade sustainability impact assessment in relation to the human rights impact assessment and the role and influence of the European Union and Switzerland as the international players in this field. The paper first provides a short overview of current topicalities in the field. Secondly, it defines the notion of impact assessment and its proliferation process. Then, the paper analyzes the specific impact assessments and, on their basis, suggests a theoretical model of trade sustainability impact assessment, taking into account the fact that today there is no internationally agreed framework for the assessment of trade agreements. Finally, the paper briefly discusses the potential role that the European Union and Switzerland, as the international players, might have in shaping these assessments and whether this role might be distinctive and long-term in this complex, multilateral system.

The paper is based on the analysis of the relevant documentation (political guidance documentation and legal sources) and specialized literature of the field. Traditional legal research methods were used: monographic, dogmatic and special analytical techniques.

\section{CURRENT TOPICALITIES}

Nowadays, there is the worldwide recognition that the semantic meaning of the term environment comprehends the interaction of environmental, social and economic considerations in the framework of the principle of sustainable development (International Association of Impact Assessment, 2009).

The stages, denoted by Dalal-Clayton and Sadler (2014, p. 13) as five milestone events in the development of the sustainability concept, can be distinguished as follows:

- 1987 - report of Bruntland Commission Our Common Future and following principles of Tokyo Declaration; 
- 1992 - the UN Conference on Environment and Development (so-called World Earth Summit) - adaptation of the Rio Declaration on Environment and Development, Agenda 21, the Framework Convention on Climate Change, the Convention on Biological Diversity, the Statement of Forest Principles;

- 2000 - UN Millennium Development Goals - further directing and policy focusing on the sustainable development agenda for international cooperation;

- 2002 - the UN World Summit on Sustainable Development - adaptation of the Johannesburg Declaration on Sustainable Development and the Johannesburg Plan of Implementation;

- 2012 - the UN Conference on Sustainable Development (Rio+20) renewed political commitment to sustainable development (Ekins \& Voituriez, 2009, p. 5; Dalal-Clayton \& Sadler, 2014, pp. 13-26).

193 Member States of the UN unanimously adopted the post-2015 development agenda Transforming our World: The 2030 Agenda for Sustainable Development in the Summit in New York on 25 September 2015 (UN, 2015a; 2015b; 2015d; 2015e). This process can be characterized as largely Member State-led with broad participation of diverse civil society stakeholders (UN, 2015c). The post-2015 development agenda proclaims 17 Sustainable Development goals with 169 associated targets (UN, 2015a; 2015d). One can agree with the precise wording of the Swiss Position on a Framework for Sustainable Development Post-2015 (2014) which says: "New sustainable development goals have to be embedded in a narrative of transformative change, which is needed to realise a common vision of a sustainable reduction of poverty in all its forms; social inclusion; and universal human development that respects human dignity, human rights (here and hereinafter - emphasis added) and planetary boundaries". During the opening ceremony of the Summit, the UN Secretary-General Ban Kimoon (UN, 2015e) said: "The new agenda is a promise by leaders to all people everywhere. It is a universal, integrated and transformative vision for a better world".

The process of formulating new, more overarching sustainable development principles is related to the need for policy coherence and to address shortcomings experienced with regard to reaching the objectives and mandates set out in Agenda 21, the Johannesburg Plan of Implementation and the Millennium Development Goals. In these documents, "the different issues were covered separately as sectoral issues (...) This is in direct contradiction of the concept of integration that lies at the heart of sustainable development, which seeks to promote cross-sectoral solutions" (Swiss Confederation, 2014).

In the context of the above-mentioned currently on-going topicalities, the meaning of these processes must be outlined from the point of view of effectiveness in relation to the achievement of sustainable development through the tool of impact assessment (IA). Adopting the approach of the scholars (Agrawala, Kramer, Prudent-Richard, \& Sainsbury, 2010, p. 13) to the research 
theme, the authors of the paper highlight that, generally, there are four known levels of incorporation of societal intentions operationally:

- $\quad$ high-level policy documents acknowledging such a need, formulating (the first level),

- operational guidance (the second level),

- adjustment of legal and regulatory frameworks (the third level),

- actual implementation - practice cases (the fourth level).

In the rest of the paper, the references to these levels will be reiterated; however, preliminary need reveals that in relation to sustainable development the situation is progressing at a slow pace. The high-level policy documents are continuously formulated and re-formulated, whereas the progress at lower levels lags behind considerably.

\section{HISTORICAL BACKGROUND AND CURRENT SITUATION IN THE FIELD OF IMPACT ASSESSMENTS}

The International Association of Impact Assessment (2009) defines IA as "the process of identifying the future consequences of a current or proposed action". The first known IA was an environmental impact assessment (EIA) introduced in the USA in 1969 (by the National Environmental Policy Act) as an important environmental decision-making tool (Agrawala et al., 2010, p. 8; International Association of Impact Assessment, 2009; Walker, 2009, p. $3)$. The traditional concept of EIA is a procedure used for the removal or reduction of adverse effects of proposed activity in the natural environment. In other words, it could be defined as the process for assessing the impact of a proposed project on the environment before deciding on whether or not to undertake the project, as well as developing and applying measures to avoid or minimize those impacts as conditions of approval for the project (Agrawala et al., 2010, p. 8). The International Association of Impact Assessment (2009) has adopted the following definition of EIA: "the process of identifying, predicting, evaluating and mitigating the biophysical, social, and other relevant effects of development proposals prior to major decisions being taken and commitments made". The EIA is "applied to a wide range of policy, developmental, and geographical settings" and "institutionalized as a formal separate process under various legal and institutional arrangements established by countries, provincial jurisdictions, and international organizations" (Sadler, 1996, p. 12).

Over the last 40 years, due to its international recognition, the EIA has been joined by a growing family of different IA tools (Dalal-Clayton \& Sadler, 2014; Glasson, Therivel, \& Chadwick, 2012, p. 21; Harrison, 2010, p. 3; International Association of Impact Assessment, 2009; Walker, 2009, p. 5) .

According to IA community commentators and the view of the authors of this paper, IA can be distinguished in several generations:

- first generation is represented by (project level) EIA - "now well established with internationally accepted norms" and legal frame- 
works (e.g., EIA Directive with its amendments and codified version in 2011);

- second generation comprises of strategic environmental assessment (SEA) for policy, plan and program proposals, and is "at an earlier phase of process evolution and application," widely accepted and frequently embedded in the legal framework (Morrison-Saunders \& Arts, 2004, p. 260) (e.g., SEA Directive 2001/42/EC) ;

- third generation - diverse sub-types of impact assessment, for example, social impact and health impact assessment, known as the most famous, among others, which generally are not institutionalised through regulatory mechanisms;

- fourth generation refers to sustainability analysis, sustainability assurance, sustainability impact assessment, sustainability assessment and integrated environmental management; these integrated approaches are also still at the so-called prototype stage, i.e., not yet institutionalized (Dalal-Clayton \& Sadler, 2004; Morrison-Saunders \& Arts, 2004, p. 260; International Association of Impact Assessment, 2009).

On one hand, the authors of this paper believe that the IA (taken even just as the first generation EIA instrument) is specifically geared to respond to some of the world's most pressing environmental and developmental challenges. On the other hand, the authors note that just first generation IA (i.e., EIA) and partially second generation IA (i.e., SEA) are legally embedded in legal frameworks of the countries and are covered by a large number of provisions of international conventions (International Association of Impact Assessment, 2009). Other types of IA are based on policy documents and, in the best case, also on operational guidance. This makes them weaker tools in the implementation process. In addition, one commonly approved approach regarding the definition and classification of IA does not exist; rather, the focus in specialized literature and within international forums is put on the analysis of different kinds of the IA, rarely providing one holistic view or integrated method. For example, Dalal-Clayton \& Sadler (2014, p. 388) comment that "there is still very little application in development cooperation of fully integrated (particularly linking the economic and socio-environmental dimensions) and holistic approaches to assessment and appraisal that would satisfy the principles of sustainability appraisal". Therefore, the way to achieve "perfect" sustainability appraisal (i.e., fourth generation) might be a very long process. Also, the recent proliferation of the IA methods and processes has caused certain confusion among practitioners, policy-makers and scholars (Sadler, 2011, p. 446) or, in other words, "[a]long with their various derivatives, relating to specific sub-fields, the alphabet soup of acronyms currently makes for a confusing picture" (Dalal-Clayton \& Sadler, 2004). Although these words were written more than 10 years ago, the situation has become worse with time, as the multiplicity of the IA has progressed with tremendous speed both at international and regional levels. 


\section{TRADE SUSTAINABILITY IMPACT ASSESSMENTS}

Nowadays, it is widely recognized that a rules-based, open, non-discriminatory, and equitable multilateral trading system enhancing the complementarity between trade and the environment is also a key precondition for advancing sustainable development and better protection and conservation of environmental resources (Dalal-Clayton \& Sadler, 2014, p. 628; Swiss Confederation, 2014). This recognition has "increasingly been strengthened as a general trend" (Steiner, 2011, p. 296). The process gradually started in the 1990s when, becoming aware of the fact that so-called globalization of market and trade liberalization might have negative consequences, the first formal trade IA tools were introduced - Canadian and US methodologies (North America Commission on Environmental Cooperation, North American Free Trade Agreement), trade sustainability impact assessment (the European Union (EU)), strategic impact analysis (Organisation for Economic Co-operation and Development), integrated assessment for trade related policies (United Nations Environment Programme), and proposed model by World Wide Fund for Nature (Abaza \& Hamwey, 2001; Dalal-Clayton \& Sadler, 2014, pp. 640-659). In the framework of this paper, these terms altogether will be defined as "trade sustainability impact assessment" (TSIA), whereas the analysis will be mainly based on the model of the EU. To date, it is the only institution that covers all three pillars of sustainable development with application to trade policy (Dalal-Clayton \& Sadler, 2014, p. 652). Its proposed model has received international recognition and has also been used as "perhaps the most far-reaching initiative world-wide" at the multilateral level of the World Trade Organisation's negotiations (Dalal-Clayton \& Sadler, 2014, p. 652; George \& Kirkpatrick, 2008, p. 69).

In 1999, the European Commission (Commission) decided to integrate sustainable development into trade negotiations and launched a new assessment tool - TSIA (Commission, 2006, p. 5; Alam, 2008, pp. 125-126; Orbie \& Tortell, 2009, p. 153) in the run-up to the Ministerial Meeting in Seattle on the initiative of the former EU Trade Commissioner Pascal Lamy. It represented a response to increasing public criticism of trade liberalization and its perceived impact on environmental and social standards (Žvelc, 2012, pp. 186-187).

TSIA is defined as "a process undertaken during a trade negotiation which seeks to identify the potential economic, social and environmental impacts of a trade agreement" (Commission, 2005, p. 7), or as "a new assessment tool for trade negotiators, NGO's and other relevant stakeholders to identify the social and environmental impact of trade agreements, and to stimulate initiatives that would yield the most beneficial outcome in terms of trade, economic growth and the environment" (Alam, 2008, p. 126). Finding the equilibrium of these elements has become one of the most challenging issues in light of global partnerships (Steiner, 2011, p. 296). As Dalal-Clayton and Sadler (2014, p. 663) explain, "[d]espite their rationale, some 15 years of experience of these assessments suggests that they have had very little impact on trade negotiating agendas" and "[a]bove all, there seems to be general consensus that the 
most important challenges for trade impact assessments is their lack of policy relevance". Ekins and Voituriez $(2009$, p. 2) state that to date TSIA has "done little to benefit trade negotiations because the hurdles trade negotiations need to surmount have in fact changed [since its beginnings], in spite of superficial similarities, as well as, it has failed to address a number of important factors that cause negotiators to resist free trade today".

\section{HUMAN RIGHTS INTEGRATION}

Along with TSIA, the development of human rights impact assessment (HRIA) was initiated in the late 1990s (Harrison, 2010, p. 3) as "part of a growing effort by the human rights community to operationalize the relevance of human rights in various fields, including development, and thus to advance an understanding of the ways in which public policies and development projects affect the enjoyment of people's rights" (Felner, 2013). "There has been widespread criticism of, and mobilization against, trade agreements and investment treaties, particularly given governments' orientation to focus exclusively on commercial interests in negotiations without taking into account their obligations to address human rights, the environment and development" (Berne Declaration, Canadian Council for International Co-operation \& Misereor, 2010).

HRIA has been defined as "measuring the impact of policies, programmes, projects and interventions on human rights" (Harrison, 2010a, p. 4; Harrison, 2009 , p. 1). HRIA could be precisely characterized as looking "at the various dimensions of sustainable development from a human rights perspective. Accordingly, [it] may disregard certain elements that are relevant to sustainable development, but not to human rights" (Bürgi Bonanomi, 2014, p. 25).

Many studies, analyzing HRIA, refer to the UN "Guiding Principles on Business and Human Rights" (UN, 2011a). Also, there are the known International Finance Corporation Guidelines "Guide to Human Rights Impact Assessment and Management" (International Business Leaders Forum \& International Finance Corporation, 2011). These are the precursors to the most concise and innovative trade HRIA framework in relation to TSIA UN “Guiding Principles on Human Rights Impact Assessments of Trade and Investment Agreements" (presented at the UN General Assembly by the UN Special Rapporteur on the Right to Food, Olivier de Schutter) (UN, 2011b; Bürgi Bonanomi, 2014, p. 6). The Guiding Principles (UN, 2011b, p. 5) state that HRIA is "a tool to ensure consistency and coherence between the obligations of States under international law and other international agreements to which they are parties, and thus to overcome, or at least mitigate, the problems resulting from the fragmentation of international law". In the case of TSIA, HRIA is "a tool for States negotiating trade or investment agreements to ensure that the conclusion of such agreements will not lead these States to violate their human rights obligations or to be unable to fulfil such obligations" (UN, 2011b, p. 11). 
Although until recently human rights were not a compulsory ingredient of the TSIA, to date in the EU there have been six so-called new generation TSIA done (with some others in the process) in order to evaluate a new generation of free trade agreements - deep and comprehensive free trade agreements (DCFTA) . However, there are the following important challenges that need to be addressed:

- "European trade negotiators do not negotiate on behalf of other countries but on behalf of Europe" (George \& Kirkpatrick, 2008, p. 69) and "human rights-sensitive [TSIA] conducted by the EU will always remain limited, as one trade partner passes judgment on the other from its own perspective" (Bürgi Bonanomi, 2014, p. 7);

- when analyzing the new generation TSIAs, there is the evidence that they primarily focus on the EU's trading partners, however, "practice needs to be consistent in assessing human rights impacts both at home and in the partner country" (Bürgi Bonanomi, 2014, p. 14);

- there is always a constant threat that the trade agreements will be concluded prior to TSIA study (George \& Kirkpatrick, 2008, p. 83; Dalal-Clayton \& Sadler, 2014, pp. 660-661);

- at the same time - "the EU assessments have been widely accused of taking an excessively pro-liberalisation stance" (Harrison, 2009, p. 7).

These observations lead to the conclusion that it would be more appropriate that the HRIA are conducted by parallel mechanisms that could be developed using either multi-country, human rights-sensitive TSIA models (Harrison, 2009, p. 7 ) at the regional level or at the international level in terms of global partnership and global governance (George \& Kirkpatrick, 2008, pp. 78-79, 87). As well as, there would be a need for seeing HRIA not as "one-off policy but ongoing and dynamic process" (Harrison, 2010, p. 22). Thus, ex ante HRIA could be undertaken before the conclusion of the agreement and ex post HRIA would be incorporated in freed trade agreement as a systematic monitoring tool (Cismas, 2013). One must agree that "a strong human rights framework carries with it a number of advantages for business, since it contributes to stronger economic integration and potentially reduces costs of economic operations" (Cismas, 2013).

\section{ClimATE CHANGE INTEGRATION}

Climate change is one of the most challenging issues worldwide, posing a real threat to human rights. The links between human rights and the environment are now widely recognized, strengthened by the adoption of different environmental conventions, case law, and activities of human rights bodies (Sands, Peel, Fabra, \& MacKenzie, 2012, p. 776). Human rights issues increasingly arise in relation to environmental refugees forced to flee areas due to climate change (Sands et al., p. 776), which is becoming a new discipline of law (Peel, 2008), and because international environmental law raises many 
issues which are similar to human rights law (Sands et al., 2012, p. 775). Thus, "human rights law could conceivably frame an approach to climate change" (Intergovernmental Panel on Climate Change, 2014b, p. 1027), which has been acknowledged in several UN documents (United Nations Human Rights Council, 2008, 2009).

In the literature, it is indicated that "[a]lready today, there are more refugees because of global warming than because of war and civil war" (Gabriel, 2009 , p. 9). In addition, "[i]t is widely acknowledged that migration has had a major impact on the achievements of the [Millennium development goals] without being formally reflected in the current framework" (Swiss Confederation, 2014).

Moreover, the connection between IA and climate change is much more evident than it might seem. In this context it is worth mentioning that Directive 2014/52/EU of the European Parliament and of the Council of April 16, 2014 introduced the "climate proofing" into EIA and envisaged the evaluation of the impact that the adverse effects of climate change might cause to a proposed activity. Before, the EIA legal framework did not expressly address climate change, but instead required just the description, identification and assessment in an appropriate manner of relation to direct and indirect effects of a project on climate, among other factors. The authors find that a similar approach, as it is used in Directive 2014/52/EU, could be applied in the case of TSIA.

Firstly, one can agree that "trade can play a valuable role in helping humankind adapt to the consequences of a warmer future. (...) Trade can provide a means to bridge differences in demand and supply, so that countries where climate change creates scarcity are able to meet their needs by importing from countries where these goods and services continue to be available" (World Trade Organisation-United Nations Environment Programme, 2009).

Secondly, in order to take advantage of the above-mentioned benefits of trade, it is necessary to assess them appropriately in terms of environmental considerations, taking into account both mitigation and adaptation measures, as well as risk disaster management.

Thirdly, considering the unclear picture of environmental refugee status, there is a need for formulation of the rights of environmental refugees (e.g., Docherty \& Giannini, 2009; Intergovernmental Panel on Climate Change, $2014 a$, p. 771). It is of the utmost importance, as "[r]eferences in impact assessments to development goals or to poverty (...) are not a substitute for a reference to the normative components of human rights" and HRIA content shall be based "explicitly on the normative content of human rights" (UN, 2011b, p. 11). As results from Figure 1 show, the evaluation of the measures for action for environmental refugees must be worked out, as well as the integration of their rights into HRIA. 


\section{HOLISTIC, INTEGRATED APPROACH TO TRADE SUSTAINABILITY IMPACT ASSESSMENT IN LIGHT OF SUSTAINABLE DEVELOPMENT}

Many studies have been undertaken to shed light on more effective application of TSIA. However, it is rightly stated that TSIA is "never a finished product: each new study contributes to developing the methodology and adds new insight" (Commission, 2006, p. 39). "It is widely recognized that there is no one-size-fits-all approach for trade assessment" (Dalal-Clayton \& Sadler, 2014, p. 661; also for HRIA - Harrison, 2010, pp. 21, 27), neither is it possible for HRIA to stand alone. "The appropriate model will depend, to a certain extent, on the nature of what is being assessed, who is undertaking the assessment, when the assessment is taking place, as well as a series of strategic decisions made about that assessment process" (Harrison, 2010, p. 4), however, "there are key elements and considerations that should be common to all human rights impact assessment if the process undertaken is to be worthy of the nomenclature" (Harrison, 2010, p. 4).

The authors argue of a need for a TSIA general frame that would allow differentiated approaches and contextual, country-specific adaptation (e.g., in relation to the content of the assessments as in the case of HRIA where the information on the most vulnerable groups is broken down by gender, disability, age group, region, and ethnicity).

In line with community commentators, the authors argue that the three pillars of sustainable development have to be integrated within one single evaluation process, i.e., one single TSIA (Bürgi Bonanomi, 2014, p. 25; Voituriez, Ekins, Blanco, Von Homeyer, \& Scheer, 2009, pp. 88-89). While this seemingly builds on the traditional methodology, it aims to reflect the theoretical comprehensive structure of TSIA (the so-called, ideal model), based on classical IA theory. In Figure 1, the structure of the methodological framework for TSIA is outlined. The main focus of this frame is the assessment of environmental, social and economic aspects, being considered not individually (Voituriez et al., 2009, pp. 88-89), but in mutual interconnectedness. Also, as some NGO's (World Wide Fund for Nature, 2004) have offered, it would be necessary to start with the aim or reachable result of sustainable development by working backwards towards the appropriate trade measure. This would mean that the environmental considerations must be set as first, and, secondly, followed by the economic analysis. This is so-called "environment first assessment of the basis for sustainable trade activity" (Dalal-Clayton \& Sadler, 2014, p. 663). "This would involve establishing sustainability objectives in their different dimensions and identifying which scenarios or groups of trade measures would be most likely to reach those objectives" (World Wide Fund for Nature, 2004). In turn, the impact of economic analysis should be modified according to social considerations that include HRIA (including the rights of environmental refugees).

The division of the scheme into two parts (see figure 1) means that all the steps and considerations must be done on two sides (country 1 and country 2). 
Journal of Education Culture and Society No. 1_2017

The model operates as a tool of parallel mechanisms, simultaneously applied to all the parties of the trade agreement.

Fig. 1. Theoretical comprehensive structure of the TSIA and interactions between integrated assessments (modelling on bilateral agreement)

\section{TRADE SUSTAINABILITY IMPACT ASSESSMENT}

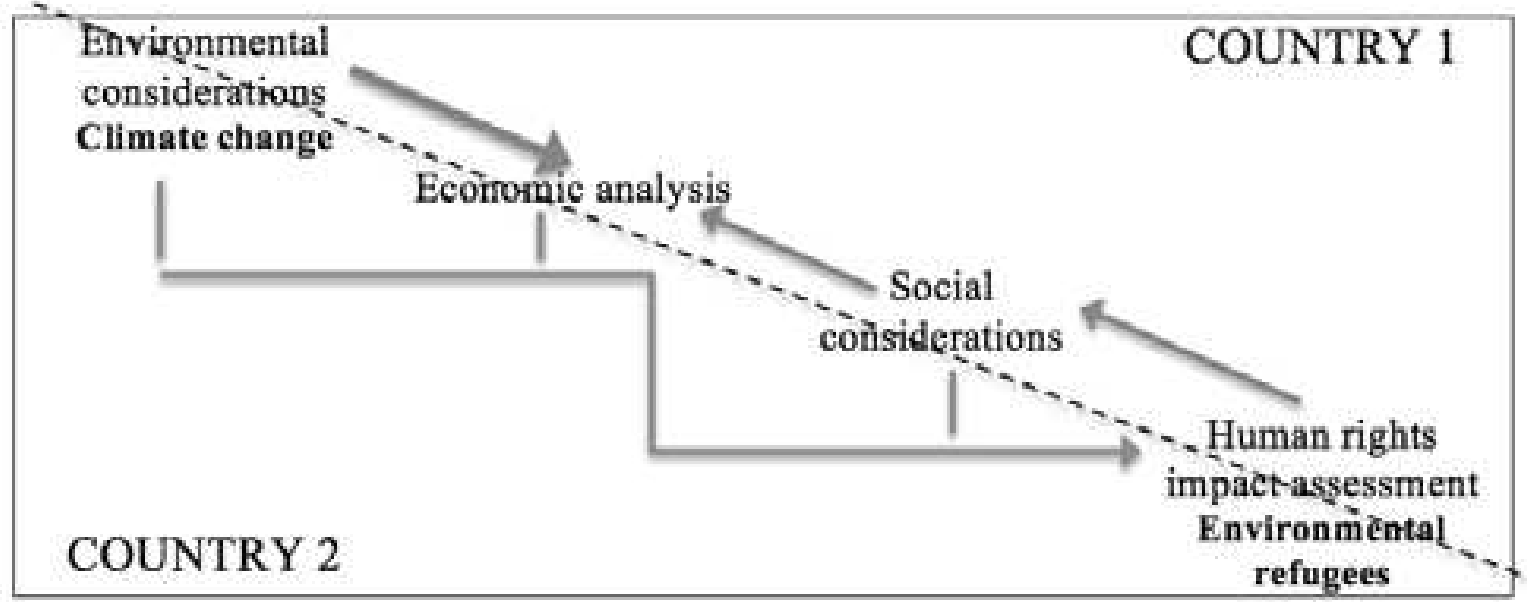

Source: prepared by the authors of the paper

In the application of this model, care should be taken, however, not to make classical mistakes because its amplitude might affect timing and meaningful input (informed public participation). An equilibrium must be found to redress the tension between the need to cover a vast array of sustainable development issues and to remain practical and operational (Dalal-Clayton \& Sadler, 2014, p. 662). The authors argue that a reframed and renewed concept of TSIA, similar to the concept of adaptation, will "serve as a road map and focal point to pioneer a discursive process for onward agreement and application at the global level" (Khan, 2014, p. 95).

\section{FRAMEWORK FOR ECONOMIC CONSIDERATIONS AND LEGAL POINT OF VIEW: THE ROLE OF THE EUROPEAN UNION AND SWITZERLAND}

The EU and Switzerland are economically strong and developed entities that have much influence on the economics of the world, and this aspect is the pre-condition set in order to preserve their long-standing and crucial role in shaping the politics and tools in the field where the trade, human rights, and climate change interact. In the international arena, the positions and roles of the EU and Switzerland must be evaluated in light of global partnership and global governance of adaptation for the implementation of jointly agreed objectives in the field of sustainable development. 
Both the EU and Switzerland are bound by commitment to sustainable development as a core principle and key issue across all policy areas through their policy documents and supreme law documents. "The EU has positioned itself as an international leader in promoting [the reforms in relation to sustainable development] internationally, a role that some have characterised as the exercise of green normative power" (Dalal-Clayton \& Sadler, 2014, p. 309). But Switzerland is "well positioned to build bridges" between developed and emerging economies since it maintains excellent relations and effective cooperation with them (Swiss Confederation, 2014).

In the context of Swiss foreign economic policy, "the free trade agreements with its non-EU trading partners, together with its membership of the World Trade Organisation and the bilateral agreements with the EU, constitute an indispensable contribution to maintaining and enhancing the competitiveness and the attraction of Switzerland as an economic centre" (World Trade Organisation, 2013). In addition to the Free Trade Agreement with the EU of 1972, Switzerland has a network of 28 freetrade agreements with 38 partners outside the EU, most of them concluded in the framework of the European Free Trade Association (State Secretariat for Economic Affairs of Swiss Confederation, 2015). However, it has entered into some trade agreements outside this framework, as it has been in the case of Japan and China (State Secretariat for Economic Affairs of Swiss Confederation, 2015). To date, bilateral free trade agreements not occupy only a central place in Switzerland's economic outlook (Cismas, 2013) but also refer to sustainable development, environment and human rights in their preambles and dedicate a chapter to these issues (Riklin, 2013 , p. 31). Still, an overarching assessment is not applied and above-mentioned references "entail soft model provisions (...) and are characterized by the absence of continuous monitoring and by insufficient enforcement provisions" (Cismas, 2013). As the promotion and protection of human rights "is a pillar objective of Swiss foreign policy (...), human rights must be consistently taken into account in all foreign-policy activities" (Cismas, 2013).

According to Article 3(1) of the Treaty of the Functioning of the EU ([2012] OJ C 326/51), the Common Commercial Policy is the exclusive competence of the EU, and it has concluded numerous trade agreements. "The Common Commercial Policy is one of the most visible manifestations of the EU's external action. (...) The challenge is to make trade work in a way that helps rather than hinders human rights concerns" (Commission, 2011).

The EU (Commission, 2011; Council, 2012) has emphasized its commitment to the promotion of human rights in all areas of the EU's external action without exception and has also highlighted the need for establishing country-specific priorities and objectives, which can be integrated in trade using tailor-made approaches. In Swiss Position on a Framework for Sustainable Development Post-2015 (2014), it is reaffirmed that human rights (not just economic, social and cultural rights, but also civil and political human rights, including the right to take part in government, freedom of expression and opinion, freedom of peaceful assembly and association, and access to justice) are "an inte- 
gral part of sustainable development" and "form a strong legitimacy and a foundation for sustainable, inclusive development paths. They may serve as practical guidelines to design and monitor sustainable development strategies, by distinguishing between duty-bearers and rights-holders or by prioritising equal access to clean drinking water and sanitation, adequate food, clean air, land, education, adequate housing and health services".

Considering the above-mentioned, the important challenges to be addressed include the following:

- there would be a need for application of TSIA models both in the agreements of the European Free Trade Association and Swiss separate trade agreements with other countries;

- as it is suggested in UN Guiding Principles on HRIA, it would be necessary to stipulate the process of preparing HRIA in legislation, rather than leaving it as an ad hoc choice by ensuring that there are no agreements concluded that make it more difficult or impossible for the state to comply with human rights obligations (UN, 2011b, p. 3). The authors claim that in this context the EU and Switzerland might be the pioneers, thus, they are setting the international benchmark in the field of human rights development. For example, the UN Committee on Economic, Social and Cultural Rights (2010) suggested Switzerland to "undertake an impact assessment to determine the possible consequences of its foreign trade policies and agreements on the enjoyment by the population of the State party's partner countries, of their economic, social and cultural rights". "As a constitutionally proclaimed human rights promoter, Switzerland would seem to have a reputational stake in spearheading such progress" (Cismas, 2013). As the result, when "integrating human rights in the negotiations of preferential trade instruments must be seen as compulsory if the objectives of the foreign economic policy and the wider Swiss foreign policy are to be achieved" (Cismas, 2013);

- it would be appropriate, therefore, in the future, if TSIA models include both HRIA and climate change under environmental and social considerations that would be used at the multilateral level of the World Trade Organisation's negotiations and for Europe's regional and bilateral trade agreements. In combination with the stipulation of HRIA in legislation, it might be an effective mechanism to implement sustainable development through legal and regulatory frameworks in practice.

\section{CONCLUSIONS}

The UN post-2015 development agenda proclaims 17 new Sustainable Development goals. The society's ambitious intentions towards sustainable development have experienced certain shortcomings in the past, and there is a need for a new, overarching approach. However, this means that in the current state the sustainable development is incorporated mainly in the high-level 
policy documents, whereas its implementation at operational, regulatory, and practical levels lags behind.

Over the last 40 years, uncountable types of impact assessments have grown from environmental impact assessment and have proliferated into a variety of diverse associated techniques, assessment methods, and processes. The main difference between these impact assessments is that two of them (i.e., environmental impact assessment and strategic environmental assessment) are frequently embedded in the legal frameworks of the countries. In turn, other types of impact assessments are based on policy documents and, in the best case, also on operational guidance, for example, trade sustainability impact assessments and human rights assessments. There is still very little application of development cooperation for fully integrated and holistic approaches to assessment.

Trade sustainability impact assessment, as a process undertaken during a trade negotiation for identifying the potential environmental, social, and economic impacts of a trade agreement, has been criticized due to its failure to address a number of important factors that cause negotiators to resist free trade today.

In relation to human rights impact assessment, the practice observations lead to the conclusion that it would be more appropriate if this assessment be conducted by parallel mechanisms that could be developed using multi-country, human rights-sensitive trade sustainability impact assessment models (including environmental refugees rights) at either the regional or international levels in terms of global partnership and global governance.

The authors propose a theoretical, methodological framework for trade sustainability impact assessment. The main focus of this framework is that the assessment of environmental, social, and economic aspects are not considered one by one, but in mutual interconnectedness, using environment first assessment. In turn, the impact of economic analysis should be modified according to social considerations that include human rights assessments (including the rights of environmental refugees). All the steps and considerations in the implementation of the proposed model must be done on two sides (in case of bilateral agreement). The model operates as a tool of parallel mechanisms, simultaneously applied to both states that are the parties of the trade agreement.

The authors suggest that in this context the EU and Switzerland might be pioneers, thus, setting international benchmarks in the field of human rights development; there would be a need for application of trade sustainability impact assessment models both in the agreements of the European Free Trade Association and Swiss separate trade agreements with other countries. It would be appropriate, therefore, in the future, if proposed theoretical trade sustainability impact assessment models that include both human rights impact assessment and climate change under environmental and social considerations would be used at the multilateral level of the World Trade Organisation's negotiations and for Europe's regional and bilateral trade agreements. In combination with the stipulation of human rights impact assessment in legislation, 
it might be an effective mechanism for implementing sustainable development through legal and regulatory frameworks into practice.

\section{REFERENCES}

[1] Abaza, H., \& Hamwey, R. (2001). Integrated Assessment as a Tool for Achieving Sustainable Trade Policies. Retrieved from http:/ / www.unep.ch/etu/etp/acts/manpols/iaia.pdf.

[2] Agrawala, S., Kramer, A. M., Prudent-Richard, G., \& Sainsbury, M. (2010). Incorporating climate change impacts and adaptation in Environmental Impact Assessments: Opportunities and Challenges. OECD Environmental Working Paper, No. 24. Paris: OECD Publishing. DOI: $10.1787 / 5 \mathrm{~km} 959 \mathrm{r} 3 \mathrm{jcm}$-en.

[3] Alam, S. (2008). Sustainable development and free trade: Institutional approaches. London: Routledge.

[4] Berne Declaration, Canadian Council for International Co-operation \& Misereor. (2010). Human Rights Impact Assessments for Trade and Investment Agreements.Report of the Expert Seminar. Retrieved from http:/ / www2.ohchr.org/english/issues/food/docs/report_ hria-seminar_2010.pdf.

[5] Bürgi Bonanomi, E. (2014). EU Trade Agreements and Their Impacts on Human Rights. Study Commissioned by the German Federal Ministry for Economic Cooperation and Development (BMZ). CDE Working Paper 1. Bern, Switzerland: Centre for Development and Environment $(\mathrm{CDE})$.

[6] Cismas, I. (2013). The integration of human rights in bilateral and plurilateral free trade agreements: arguments for a coherent relationship with reference to the Swiss context. Currents: International Trade Law Journal, 21 (2).

[7] Council of the European Union (2012). EU Strategic Framework and Action Plan on Human Rights and Democracy. Retrieved from https://www.consilium.europa.eu/uedocs/cms_ data/docs/pressdata/EN/foraff/131181.pdf.

[8] Dalal-Clayton, B., \& Sadler, B. (2014). Sustainability appraisal: A sourcebook and reference guide to international experience. Oxon: Routledge.

[9] Dalal-Clayton, B., \& Sadler, B. (2004). Part 1. Sustainability appraisal: a review of international experience and practice, first draft of work in progress. International Institute for Environment and Development. Retrieved from http:/ / pubs.iied.org/pdfs/G02173.pdf?

[10] Docherty, B., \& Giannini, T. (2009). Confronting a Rising Tide: A Proposal for a Convention on Climate Change Refugees. Harvard Environmental Law Review, 33, 349-403.

[11] Ekins, P., \& Voituriez, T. (2009). Overview and general introduction. In: P. Ekins \& T. Voituriez (Eds.), Trade, globalization and sustainability impact assessment (pp. 1-16). London: Earthscan.

[12] European Commission. (2011). Joint Communication to the European Parliament and the Council: Human Rights and Democracy at the Heart of EU External Action - Towards a More Effective Approach. Brussels, COM (2011) 886 final.

[13] European Commission. (2006, October). Handbook for Trade Sustainability Impact Assessment.

[14] Felner, E. (2013). Human Rights Impact Assessments: A Review of the Literature, Differences with other Forms of Assessments and Relevance for Development. The World Bank. Retrieved from http://siteresources.worldbank.org/PROJECTS/Resources/40940-1331068268558/ HRIA_Web.pdf.

[15] Gabriel, S. (2009). Energy Consumption Challenge of the Industrialized World: An Overview of German Climate Policy. In: F. Dodds, A. Higham, \& R. Sherman (Eds.), Climate Change and Energy Insecurity (pp. 9-17). London: Earthscan.

[16] George, C., \& Kirkpatrick, C. (2008). Sustainability impact assessment of trade agreements: From public dialogue to international governance. Journal of Environmental Assessment Policy and Management, 10(1), 67 - 89.

[17] Glasson, J., Therivel R., \& Chadwick A. Introduction to Environmental Impact Assessment. Fourth edition. Oxon and New York, NY: Routledge. 
[18] Harrison, J. (2010a). Measuring Human Rights: Reflections on the Practice of Human Rights Impact Assessment and Lessons for the Future. Warwick School Research Paper, 2010(26).

[19] Harrison, J. (2010b). Human Rights Impact Assessments of Trade Agreements: Reflections on Practice and Principles for Future Assessments. A Paper for the Expert Seminar on Human Rights Impact Assessments of Trade and Investment Agreements, Geneva.

[20] Harrison, J. (2009). Conducting a human rights impact assessment on the Canada-Colombia free trade agreement: Key issues. Canada's Coalition to End Global Poverty.

[21] International Association of Impact Assessment. (2009). What is Impact Assessment? Retrieved from http://www.iaia.org/publicdocuments/special-publications/What\%20is\%20IA_web. pdf.

[22] International Business Leaders Forum \& International Finance Corporation. (2011, September). Guide to human rights impact assessment and management. Retrieved from www.ifc. org/hriam.

[23] Intergovernmental Panel on Climate Change (2014a). Climate Change 2014: Impacts, Adaptation, and Vulnerability. Part A: Global and Sectoral Aspects. Contribution of Working Group II to the Fifth Assessment Report of the Intergovernmental Panel on Climate Change. C. B. Field, V. R. Barros, D. J. Dokken, K. J. Mach, M. D. Mastrandrea, T. E. Bilir et al. (Eds.). Cambridge, UK, New York, NY: Cambridge University Press.

[24] Intergovernmental Panel on Climate Change (2014b). Climate Change 2014: Mitigation of Climate Change. Contribution of Working Group III to the Fifth Assessment Report of the Intergovernmental Panel on Climate Change.O. Edenhofer, R. Pichs-Madruga, Y. Sokona, E. Farahani, S. Kadner, K. Seyboth et al. (Eds.). Cambridge, UK, New York, NY: Cambridge University Press.

[25] Khan, M. R. (2014). Toward a binding climate change adaptation regime: A proposed framework. Oxon: Routledge.

[26] Morrison-Saunders, A., \& Arts, J. (2004). Assessing impact: Handbook of EIA and SEA followup. Oxon: Earthscan, 2004.

[27] Orbie, J., \& Tortell, L. (2009). The European Union and the social dimension of globalization: How the EU influences the world. Oxon: Routledge.

[28] Peel, J. (2008). Climate change law: the emergence of a new legal discipline. Melbourne University Law Review, 32 (3). Retrieved from http:/ / ssrn.com/abstract=2030523.

[29] Riklin, K. (2013). Reconciling Economic, Social and Environmental Objectives. In: D. Bratanov (Ed.), EFTA bulletin. EFTA Free Trade Relations. Retrieved from http:/ / www.efta.int/sites/ default/files/publications/bulletins/EFTA-Bulletin-2013.PDF.

[30]Sadler, B., Aschemann R., Dusik J. (2011). Handbook of strategic environmental assessment. London and New York, NW: Earthscan.

[31]Sadler, B. (1996). Environmental assessment in a changing world: Evaluating practice to improve performance. Canada: Canadian Environmental Assessment Agency.

[32] Sands, P., Peel, J., Fabra, A. \& MacKenzie, R. (2012). Principles of international environmental law (3rd ed.). New York: Cambridge University Press.

[33] State Secretariat for Economic Affairs of Swiss Confederation (2015). Free Trade Agreements. Retrieved from http://www.seco.admin.ch/themen/00513/00515/01330/index. html?lang=en.

[34] Steiner, A. (2012). Measuring Progress: Environmental Goals \& Gaps. Retrieved from http:/ / www.unep.org/geo/pdfs/geo5/Measuring_progress.pdf.

[35] Steiner, S. (2011). Global Poverty and Sustainable Development: Challenges addressed by the EU's Renewed Sustainable Development Strategy. In: F. Duncan (Ed.), Global justice and sustainable development (pp. 291-305). Leiden: Martinus Nijhoff publishers.

[36] Swiss Confederation (2014). Swiss Position on a Framework for Sustainable Development Post-2015. Retrieved from https://www.eda.admin.ch/dam/post2015/en/documents/ recent/position_ch_post-2015_en.pdf.

[37]Swiss Federal Council (2016). Sustainable Development Strategy. Retrieved from http:// www.are.admin.ch/sds.

[38] United Nations (2015a). Transforming our World: The 2030 Agenda for Sustainable Development. United Nations. Retrieved from https://sustainabledevelopment.un.org/content/ documents/21252030\%20Agenda\%20for\%20Sustainable\%20Development\%20web.pdf. 
[39] United Nations (2015b). Sustainable development knowledge platform.United Nations Sustainable Development Summit 2015. Retrieved from https://sustainabledevelopment.un.org/ post2015/summit.

[40] United Nations (2015c). Sustainable development knowledge platform. Post-2015 process. Description. Retrieved from https://sustainabledevelopment.un.org/post2015.

[41] United Nations (2015d). Post-2015 process. Documents. Press release. Historic New Sustainable Development Agenda Unanimously Adopted by 193 UN Members. Retrieved from https:// sustainabledevelopment.un.org/content/documents/8371Sustainable\%20Development $\% 20$ Summit_final.pdf.

[42] United Nations (2015e). Post-2015 process. Documents. Press Materials for Sustainable Development Summit. Retrieved from https://sustainabledevelopment.un.org/content/documents/8376Summit\%20Daily\%20wrap-up_25\%20Sep_for\%20Media.pdf.

[43] United Nations Environment Programme (2012). Measuring Progress: Environmental Goals \& Gaps. Retrieved from http://www.unep.org/geo/pdfs/geo5/Measuring_progress.pdf.

[44] United Nations (2011a). Guiding Principles on Business and Human Rights: Implementing the United Nations "Protect, Respect and Remedy" Framework. Final Report of the Special Representative of the Secretary-General on the Issue of Human Rights and Transnational Corporations and other Business Enterprises, John Ruggie. A/HRC/17/31.

[45] United Nations (2011b). Guiding Principles on Human Rights Impact Assessments of Trade and Investment Agreements. Report of the Special Rapporteur on the Right to Food, Olivier de Schutter. A/HRC/19/59/Add.5.

[46] United Nations Committee on Economic, Social and Cultural Rights (2010). Concluding Observations of the Committee on Economic, Social and Cultural Rights. Switzerland. E/C.12/ $\mathrm{CHE} / \mathrm{CO} / 2-3$

[47] United Nations Human Rights Council (2009). Report of the Office of the United Nations High Commissioner for Human Rights on the Relationship between Climate Change and Human Rights. Geneva. Retrieved from http://daccess-dds-ny.un.org/doc/UNDOC/GEN/ G09/103/44/PDF/G0910344.pdf?OpenElement.

[48] United Nations Human Rights Council (2008). Human Rights and Climate Change. Geneva. Retrieved from http://ap.ohchr.org/documents/E/HRC/resolutions/A_HRC_RES_7_23. pdf.

[49] Voituriez, T., Ekins, P., Blanco, H., Von Homeyer, I., \&Scheer, D. (2009). Trade SIAs and the new challenges of trade liberalization. In: P. Ekins \& T. Voituriez (Eds.), Trade, globalization and sustainability impact assessment (pp. 87-100). London: Earthscan.

[50] Walker, S. (2009). The future of human rights impact assessments of trade agreements. Antwerpen: Intersentia.

[51] World Trade Organisation (2013). Reports by Switzerland and Lichtenstein. Retrieved from https://www.wto.org/english/tratop_e/tpr_e/g280_e.pdf.

[52] World Trade Organisation-United Nations Environment Programme (2009). Trade and Climate Change. Report. Retrieved from https://www.wto.org/english/res_e/booksp_e/ trade_climate_change_e.pdf

[53] World Wide Fund for Nature (2004). Sustainability assessments of trade policies and programmes. Retrieved from assets.panda.org/downloads/safinaltechrepfeb26vswebsite.pdf.

[54] Žvelc, R. (2012). Environmental integration in EU trade policy: The generalised system of preferences, trade sustainability impact assessments and free trade agreements. In: E. Morgera (Ed.), The external environmental policy of the European Union (pp. 174-203). Cambridge: Cambridge University Press. 